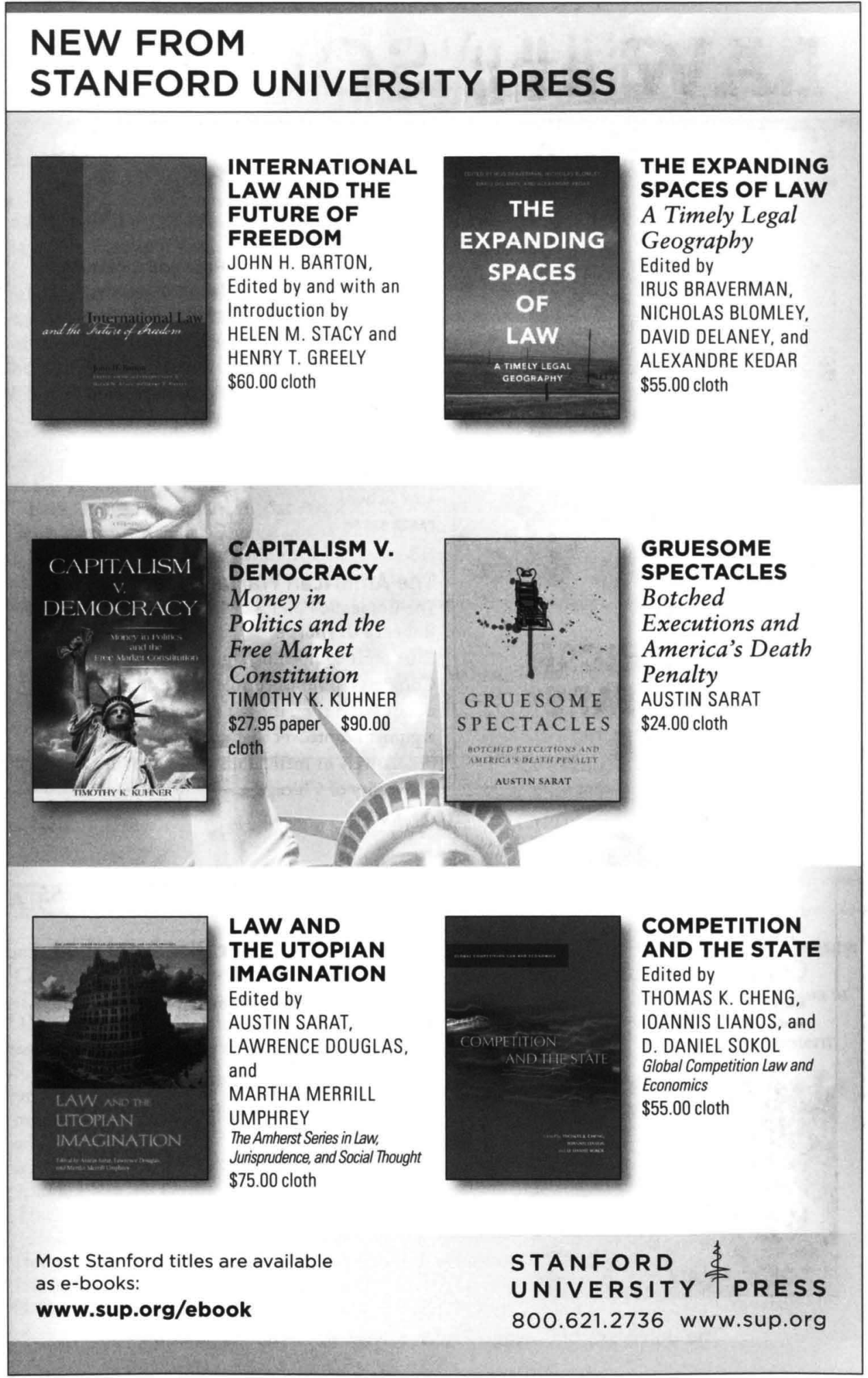




\section{LAW and SOCIETY}

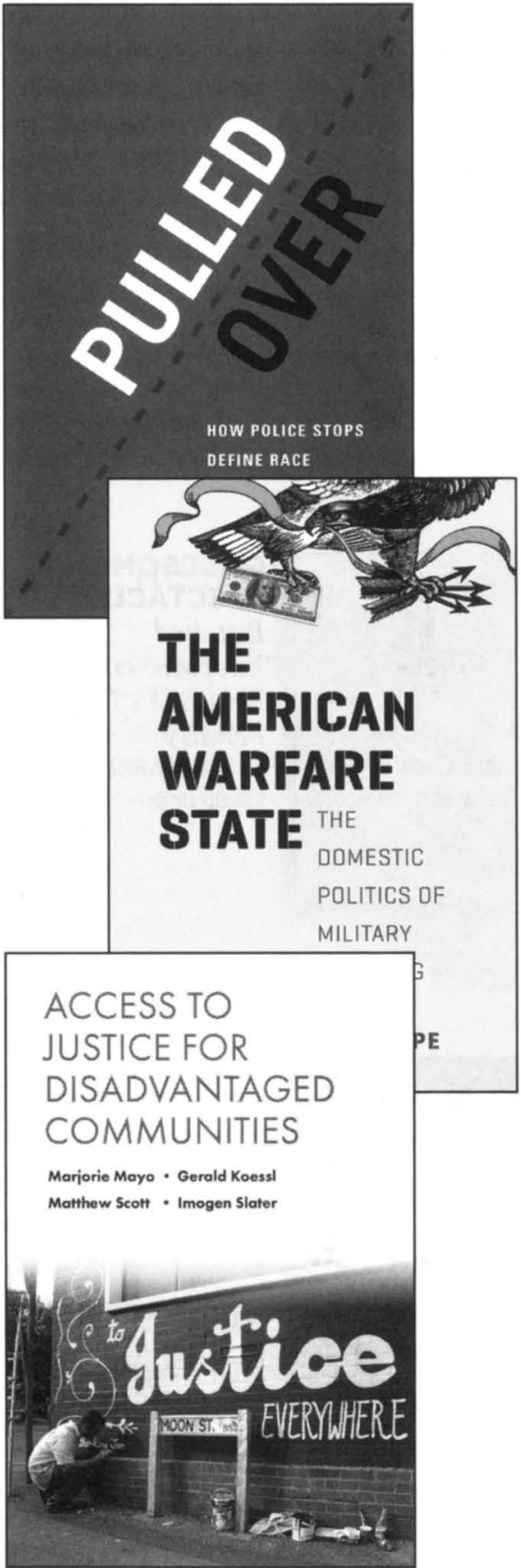

\section{Pulled Over}

How Police Stops Define Race and Citizenship

Charles R. Epp, Steven Maynard-Moody, and Donald P. Haider-Markel

"The authors expose the willful racial blindsight of police and the courts to the evolution of the 'investigatory stop' from its modest role in fighting crime to a sharp-edged weapon that corrodes the cirizenship and belonging of African Americans and Latinos."-Jeffrey A. Fagan, Columbia Law School

PAPER $\$ 25.00$

\section{The American Warfare State}

The Domestic Politics of Military Spending Rebecca U. Thorpe

"The most compelling argument I have seen for Congress's diminished role in the domestic politics of war during the last half-century. It's an argument moreover that no one has advanced so persuasively or meticulously."-William Howell, University of Chicago PAPER \$25.00

FROM $\underline{\sim}$ P POLICY PRESS

\section{Access to Justice for Disadvantaged}

\section{Communities}

Marjorie Mayo, Gerald Koessl, Matthew Scott, and Imogen Slater

"This exhaustive review of the history of legal aid and advice, and of the Coalition government's determination to destroy it, reminds us of how much other struggles to defend welfare depend on it. It is a must-read."-Gary Craig, Durham University

CLOTH $\$ 99.00$

The University of Chicago Press - www.press.uchicago.edu 


\section{American Bar Foundation}

\section{BOARD OF DIRECTORS}

President, The Honorable Bernice B. Donald, United States Court of Appeals for the Sixth Circuit • Vice President, David A. Collins, of the Michigan Bar • Secretary, Ellen J. Flannery, of the District of Columbia Bar • Treasurer, George S. Frazza, of the New York Bar

Susan Frelich Appleton, Washington University School of Law • Jimmy K. Goodman, of the Oklahoma Bar • Kay H. Hodge, of the Massachusetts Bar $\bullet$ David S. Houghton, of the Nebraska Bar $\bullet$ Chief Justice Wallace B. Jefferson, Supreme Court of Texas $\bullet$ Wm. T. Robinson III, of the Kentucky Bar • The Honorable Ellen F. Rosenblum, of the Oregon Bar • E. Thomas Sullivan, University of Vermont $\bullet$ Walter L. Sutton, Jr., of the Texas Bar • David B. Wolfe, of the New Jersey Bar

ex officio:

James R. Silkenat, President-Elect, American Bar Association - William C. Hubbard, President-Elect, American Bar Association • Robert M. Carlson, Chair, House of Delegates, American Bar Association • Lucian T. Pera, Treasurer, American Bar Association • Christopher L. Griffin, American Bar Endowment • Palmer Gene Vance II, Chair, Council of the Fund for Justice and Education, American Bar Association • Daniel B. Rodriguez, Dean, Northwestern University School of Law • Don Slesnick, Chair-Elect, The Fellows of the American Bar Foundation - Cheryl I. Niro, Secretary, The Fellows of the American Bar Foundation • Kathleen J. Hopkins, Secretary, The Fellows of the American Bar Foundation

Special Advisors:

Leonard H. Gilbert, of the Florida Bar • Myles V. Lynk, Arizona State University Sandra Day O'Connor College of Law $\bullet$ Lauren Stiller Rikleen, Rikleen Institute for Strategic Active Leadership • Mark Suchman, Brown University

\section{OFFICERS}

Robert L. Nelson, Director

Eileen C. Gallagher, Assistant Director for

Governance, Liaison, and Legal Affairs

\section{RESEARCH FELLOWS}

Traci Burch, Ph.D., Harvard University John L. Comaroff, Ph.D., University of London Stephen Daniels, Ph.D., University of Wisconsin

Shari S. Diamond, Ph.D., Northwestern University; J.D., University of Chicago Bryant G. Garth, J.D., Stanford University; Ph.D., European University Institute (Emeritus)

Tom Ginsburg, J.D., Ph.D., University of California at Berkeley

John Hagan, Ph.D., University of Alberta Terence C. Halliday, Ph.D., University of Chicago James J. Heckman, Ph.D., Princeton University Carol A. Heimer, Ph.D., University of Chicago John P. Heinz, LL.B., Yale University (Emeritus) Bonnie Honig, Ph.D., Johns Hopkins University Steven D. Levitt, Ph.D., Massachusetts Institute of Technology
Elizabeth Mertz, J.D., Northwestern University; Ph.D., Duke University

Janice Nadler, J.D., University of California at Berkeley; Ph.D., University of Illinois

Robert L. Nelson, J.D., Ph.D., Northwestern University

Laura Beth Nielsen, J.D., Ph,D., University of California at Berkeley

Dylan Penningroth, Ph.D., Johns Hopkins University

Jothie Rajah, Ph.D., University of Melbourne

Susan P. Shapiro, Ph.D., Yale University

Christopher L. Tomlins, Ph.D., Johns Hopkins University

Victoria Saker Woeste, Ph.D., University of California at Berkeley

\section{LIAISON RESEARCH SERVICES PROGRAM}

Clara Carson, B.S., Roosevelt University 


\section{Law \& Social Inquiry}

\section{Volume 39, Number 2, Spring 2014}

\section{ARTICLES}

Internal Contradictions of Judicial Mediation in China KWAI HANG NG AND XIN HE

Overstating the Satisfaction of Lawyers DAVID L. CHAMBERS

Legal Typologies and Topologies: The Construction of Indigenous Alterity and Its Spatialization Within the Colombian Constitutional Court DIANA BOCAREJO

How Bureaucracies Listen to Courts: Bureaucratized Calculations and European Law SCOTT L. GREER AND MARIA MARTÍN DE ALMAGRO INIESTA

Critical Junctures, Religion, and Personal Status Regulations in Israel and India HANNA LERNER

Lawyers for God and Neighbor: The Emergence of "Law as a Calling" as a Mobilizing Frame for Christian Lawyers JOSHUA C. WILSON AND AMANDA HOLLIS-BRUSKY

Strange Bedfellows: How an Anticipatory Countermovement Brought Same-Sex Marriage into the Public Arena MICHAEL C. DORF AND SIDNEY TARROW

Halfway Homeowners: Eviction and Forced Relocation in a Florida Manufactured Home Park ESTHER SULLIVAN

\section{REVIEW ESSAYS}

The Future and Legal Education: Are Law Schools Failing and, If So, How?

EDWARD RUBIN

Conceptions of Agency in Social Movement Scholarship: Mack on African American Civil Rights Lawyers

SUSAN D. CARLE

\section{BOOK NOTES}

